\title{
Effects of the selective kainate receptor antagonist ACET on altered sensorimotor gating in a genetic model of reduced NMDA receptor function
}

\author{
Gary E. Duncan ${ }^{1,2}$, Beverly H. Koller ${ }^{3}$, and Sheryl S. Moy ${ }^{1,2}$ \\ ${ }^{1}$ Department of Psychiatry University of North Carolina at Chapel Hill \\ ${ }^{2}$ Carolina Institute for Developmental Disabilities University of North Carolina at Chapel Hill \\ ${ }^{3}$ Department of Genetics University of North Carolina at Chapel Hill
}

\section{Abstract}

The pathophysiology of schizophrenia may involve reduced NMDA receptor function. Accordingly, experimental models of NMDA receptor hypofunction may be useful for testing potential new antipsychotic agents and for characterizing neurobiological abnormalities relevant to schizophrenia. We demonstrated previously that mice under-expressing the NR1 subunit of the NMDA receptor show supersensitive behavioral responses to kainic acid and that a kainate receptor antagonist normalized altered behaviors in the mutant mice $\left(N R I^{\text {neo/neo }}\right)$. The present work examined effects of another selective kainate receptor antagonist, (S)-1-(2-Amino-2carboxyethyl)-3-(2-carboxy-5-phenylthiophene-3-yl-methylpyrimidine-2,4-dione (ACET), on altered behavioral phenotypes in the genetic model of NMDA receptor hypofunction. ACET, at a dose of $15 \mathrm{mg} / \mathrm{kg}$, partially reversed the deficits in prepulse inhibition produced by the mutation. The $15 \mathrm{mg} / \mathrm{kg}$ dose of ACET was also effective in reversing behavioral effects of the selective kainate agonist ATPA. However, ACET did not significantly reduce the increased locomotor activity and rearing behavior observed in the $N R I^{\text {neo/neo }}$ mice. These findings show that a highly selective kainate receptor antagonist can affect the deficits in sensorimotor gating in the $N R I^{\text {neo/neo }}$ mice. The results also provide further support for the idea that selective kainate receptor antagonists could be novel therapeutic candidates for schizophrenia.

Section: Disease-Related Neuroscience

\section{Keywords}

Schizophrenia; glutamate; kainate receptor; Grin1; NMDA receptor; kainate receptor antagonist; acoustic startle; prepulse inhibition; NMDA receptor hypofunction

\footnotetext{
C 2012 Elsevier B.V. All rights reserved

Correspondence: Gary Duncan, Ph.D. Department of Psychiatry, 410 Taylor Hall, CB\# 7090 University of North Carolina at Chapel Hill Chapel Hill, NC 27599 Phone: 919-966-8237 Fax: 919-966-1856 gduncan@ med.unc.edu.

Publisher's Disclaimer: This is a PDF file of an unedited manuscript that has been accepted for publication. As a service to our customers we are providing this early version of the manuscript. The manuscript will undergo copyediting, typesetting, and review of the resulting proof before it is published in its final citable form. Please note that during the production process errors may be discovered which could affect the content, and all legal disclaimers that apply to the journal pertain.
} 


\section{Introduction}

Altered glutamate mediated neurotransmission has been suggested to play a role in the pathophysiology of schizophrenia. The most compelling evidence in this regard is the welldocumented effects of NMDA receptor antagonists to induce a spectrum of behavioral alterations in healthy humans that mimic positive, cognitive and affective symptoms of schizophrenia (Javitt and Zukin, 1991; Krystal et al., 1994). In addition, NMDA antagonists precipitate symptoms in stabilized schizophrenia patients (Lahti et al., 1995).

Based on the NMDA hypofunction hypothesis of schizophrenia, Mohn et al. (1999) developed a novel mutant mouse model characterized by markedly reduced expression of the NR1 subunit of the NMDA receptor. The partial disruption of NR1 subunit expression was produced by insertion of a neomycin resistance cassette into intron 20 of the NRI (Grinl) locus. This insertion mutation results in a marked under-expression of the NR1 subunit to approximately $10 \%$ of wild type values in all regions examined (Mohn et al., 1999; Ramsey et al., 2008). The homozygous $N R I^{\text {neo/neo }}$ mutant animals are sometimes referred to as NRI hypomorphic or NRI knock-down, since expression of the gene is reduced, but not eliminated.

The $N R I^{\text {neo/neo }}$ mice exhibit a number of behavioral phenotypes that support their utility to model certain behavioral characteristics of schizophrenia. These phenotypes include reduced locomotor habituation in a novel environment (Duncan et al., 2002; Mohn et al., 1999) and deficits in prepulse inhibition of acoustic startle (PPI) (Duncan et al., 2004; Duncan et al., 2006a; Duncan et al., 2006b; Fradley et al., 2005). In addition, the mutant mice show enhanced sensitivity to amphetamine-induced disruption of PPI (Moy et al., 2006). The $N R I^{\text {neo/neo }}$ mice also show marked deficits in tests of social affiliation and social aggression (Duncan et al., 2004; Halene et al., 2009; Mohn et al., 1999). Behavioral alterations in the $N R I^{\text {neo/neo }}$ mice are reduced by administration of typical and atypical antipsychotic drugs, although the atypical drugs exhibit a distinct behavioral profile compared the typical drugs in the model (Duncan et al., 2006a; Duncan et al., 2006b; Mohn et al., 1999).

We recently discovered that the $N R I^{\text {neo/neo }}$ mice exhibit an increase in sensitivity to seizure producing effects of systemically administered kainic acid, an agonist of a kainate subtype of glutamate receptors (Duncan et al., 2010). To test the hypothesis that increased kainate receptor sensitivity to endogenous glutamate could contribute to the abnormal behavioral phenotypes of the $N R I^{\text {neo/neo }}$ mice, a highly selective kainate receptor antagonist, LY382884, was given to the mice before assessment of prepulse inhibition of acoustic startle and activity in an open field (Duncan et al., 2010). The drug completely normalized the exaggerated baseline startle response of the mutant mice but had no effect on startle amplitude in the controls. LY382884 increased PPI in both wild type and control mice. The drug also reduced the hyperactivity in horizontal locomotion and rearing behavior in the $N R I^{\text {neo/neo }}$ mice, without affecting activity in the wild type mice. It is of interest that the behavioral profile of LY382884 in the mutant mice is similar to that of several atypical antipsychotic drugs tested in the model (Duncan et al., 2006a; Duncan et al., 2006b). LY382884 has relatively low potency as a kainate antagonist and penetrates the brain poorly. However, these initial studies open an interesting door of possibilities: that kainate antagonists could have efficacy in the treatment of schizophrenia. In order to further pursue this exciting prospect, the present work tested another highly selective and more potent kainate antagonist in the NR1 hypomorphic model, (S)-1-(2-Amino-2-carboxyethyl)-3-(2carboxy-5-phenylthiophene-3-yl-methylpyrimidine-2,4-dione, abbreviated ACET (Dargan et al., 2009; Jane et al., 2009). 


\section{Results}

\subsection{ACET blockade of ATPA-induced immobility}

Optimal doses for ACET efficacy in behavioral assays were determined by an initial screen, using only wild type mice, against the characteristic immobility following i.p. administration of ATPA, the tert-butyl analogue of AMPA. In previous studies, ATPA was identified as an AMPA agonist (Ornstein et al., 1996), but was later discovered to be a selective agonist of the GluK1 (formerly GluR5) kainate receptor (Hoo et al., 1999; Jane et al., 2009). In the present study, ATPA (30 mg/kg, i.p.) consistently induced a state of complete immobility and flat body posture in all mice tested. However, if the mice were picked up they would exhibit typical activation and when returned to the cage would move briefly, but then become immobile with the flat body posture. Pretreatment with a low dose of ACET (7.5 $\mathrm{mg} / \mathrm{kg}$, s.c.), given one hour before ATPA, failed to attenuate immobility. However, a higher dose of ACET $(15 \mathrm{mg} / \mathrm{kg})$ antagonized ATPA-induced behavioral suppression and all 5 mice tested at this dose demonstrated normal ambulatory activity. Therefore, we utilized 7.5 $\mathrm{mg} / \mathrm{kg}$ and $15 \mathrm{mg} / \mathrm{kg}$ as low and moderate doses of ACET for the acoustic startle and activity tests (described below).

\subsection{Receptor binding profile of ACET at non-glutamate receptors}

Although the specificity of ACET for the kainate subtype of glutamate receptors is well documented, there is no information available for potential off-target non-glutamatergic receptor selectivity. The ability of ACET to bind to a wide range of receptors was examined and results reported in the supplementary data. The receptors examined included subtypes of serotonin, norepinephrine, dopamine, histamine, acetylcholine, and monoamine transporters. Results of this screening process showed no appreciable binding affinity of ACET for any receptor tested, with Ki values ranging from 3,000 $\mathrm{nM}$ to $>10,000 \mathrm{nM}$ (Table 1, supplemental).

\subsection{Effects of ACET on acoustic startle and PPI in wild type and $N R 1^{\text {neo/neo }}$ mice}

The NRI hypomorphic mice showed the expected increased startle responses and reduced PPI, in comparison to the wild type subjects. Overall repeated measures analyses revealed significant interactions between genotype, treatment, and decibel level for amplitude $[\mathrm{F}(5,345)=3.9, \mathrm{p}=0.0019]$ and ppi $[\mathrm{F}(4,276)=3.21, \mathrm{p}=0.0135]$. The analyses also revealed significant effects of ACET dose for each measure [amplitude, interaction between genotype, dose, and decibel level, $\mathrm{F}(5,345)=3.72$, $\mathrm{p}=0.0027$; ppi, treatment $\times$ dose interaction, $\mathrm{F}(1,69)=9.81, \mathrm{p}=0.0025]$. Separate analyses were then conducted to determine treatment effects at each ACET dose $(7.5$ or $15 \mathrm{mg} / \mathrm{kg})$.

In the cohort of mice tested with the lower dose of ACET $(7.5 \mathrm{mg} / \mathrm{kg})$, repeated measures ANOVAs indicated highly significant main effects of genotype on startle amplitude $[F(1,31)=11.69, p=0.0018]$ and $\operatorname{PPI}[F(1,31)=20.74, p<0.0001]$, but no significant main effects or interactions for ACET treatment (Figures 1 and 2). In contrast, the higher dose of ACET $(15 \mathrm{mg} / \mathrm{kg}$ ) had significant effects on startle amplitude (Figure 3) and on PPI (Figure 4), dependent upon genotype. Similar to the cohort of mice used to assess the $7.5 \mathrm{mg} / \mathrm{kg}$ dose of ACET, in the cohort used to test the $15 \mathrm{mg} / \mathrm{kg}$ dose the overall repeated measures ANOVAs revealed significant main effects of genotype for startle amplitudes $[F(1,38)=26.93, p<0.0001]$ and PPI $[F(1,38)=29.33, p<0.0001]$. However, the analyses also indicated an ACET treatment $\times$ genotype interaction for amplitude $[\mathrm{F}(1,38)=5.66$, $\mathrm{p}=0.0224]$, and a highly significant main effect of ACET treatment for PPI $[\mathrm{F}(1,38)=7.93$, $\mathrm{p}=0.0077]$. 
Separate repeated measures ANOVAs conducted for the wild type and mutant mice revealed that ACET $(15 \mathrm{mg} / \mathrm{kg})$ had significant effects in the $N R l^{\text {neo }} /$ neo , but not the wild type mice. In the mutant mice, ACET produced significant decreases in startle responses [main effect of treatment, $F(1,15)=5.65, p=0.0311]$ and significant enhancement of prepulse inhibition [main effect of treatment, $\mathrm{F}(1,15)=4.55, \mathrm{p}=0.0499$ ]. However, the effect of ACET on startle response for the pulse-alone trial did not reach statistical significance for the wild type or mutant mice. The lack of significant effect of ACET on startle response for the pulse-alone trial suggests that the overall treatment effect on startle indicated by the ANOVA was due to the drug's effect on PPI.

\subsection{Effects of ACET on locomotion and rearing in wild type and $N R 1^{\text {neo/neo }}$ mice}

To examine potential effects of ACET $(15 \mathrm{mg} / \mathrm{kg})$ on locomotor activity, a separate cohort of mice was tested in the activity chambers without prior acoustic startle testing. Wild type and mutant mice were injected s.c. with vehicle or ACET (8-10 mice/group) $1 \mathrm{hr}$ before being placed in the activity chambers and data collected for $1 \mathrm{hr}$ in the chambers (Figure 5). Within-genotype analyses indicated that the significant ACET effect on locomotion was present in the $N R I^{\text {neo/neo }}$ group [treatment $\times$ time interaction, $\mathrm{F}(11,154)=2.18, \mathrm{p}=0.0179$ ]. However, post-hoc analysis indicated no significant effect of ACET for any time point for either genotype. Similar analyses on the rearing measure revealed significant interactions between treatment and time were observed in both the wild type $[\mathrm{F}(11,176)=1.9, \mathrm{p}=0.0424]$ and mutant $[\mathrm{F}(11,154)=2.33, \mathrm{p}=0.0113]$ groups but post-hoc analysis found no significant effect of ACET for either genotype at any time point.

\section{Discussion}

There is compelling need to develop better pharmacologic therapies for schizophrenia. Currently available drugs are associated with severe adverse side effects and limited efficacy for cognitive and affective dimensions of the illness. Traditional animal models have played a critical role in development of new antipsychotic drugs. However, standard models based on blocking effects of dopamine agonists have not resulted in discovery of drugs with therapeutic efficacy that is substantially better than first generation antipsychotic drugs (Lieberman et al., 2005; Swartz et al., 2007).

The present work demonstrated that the highly selective kainate receptor antagonist ACET diminished the deficits in PPI in NRI hypomorphic mice. These mutant mice represent a unique animal model of schizophrenia based on the NMDA hypofunction hypothesis of the illness. The previously demonstrated ability of therapeutically effective antipsychotic drugs to normalize behavioral abnormalities in the $N R I^{\text {neo/neo }}$ mice supports the predictive validity of the model (Duncan et al., 2006a; Duncan et al., 2006b). Accordingly, our previous work with LY382884 (Duncan et al. 2010) and the present findings with ACET suggest that selective kainate receptor antagonists could be a novel class of antipsychotic drugs.

Kainate receptors in the brain are composed of various combinations of 5 distinct subunits (designated GluK1-5 in the current IUPHAR nomenclature). Both LY382884 and ACET are selective for the GluK1 (formerly GluR5) subtype of the kainate receptor, and both drugs had similar effects to reduce startle reactivity and increase PPI in the $N R I^{\text {neo/neo }}$ mice. LY382884 also normalized the locomotor hyperactivity and increased rearing behavior observed in the mutant mice. The magnitude of response to the kainate antagonists in the with regard to reduction in startle and increased PPI in the $N R I^{\text {neo/neo }}$ is similar to that observed for other antipsychotic drugs tested in the model, including risperidone, clozapine, quetiapine, olanzapine (Duncan et al., 2006a; Duncan et al., 2006b). However, ACET had no clear effect on the increased horizontal locomotor activity or rearing associated with the mutation. Further work will be required to determine the reasons for the apparently different 
behavioral pharmacological profiles of ACET and LY382884 in the NR1 hypomorphic mice.

Preclinical studies predict low behavioral toxicity for kainate antagonists selective for the GluK1 subtype. In the present study, no reduction in locomotor activity was found in the wild type or mutant mice for ACET at a dose that was effective in normalizing the exaggerated startle and PPI deficits in the $N R I^{\text {neo/neo }}$ mice. In studies of protection from electrically induced seizures by a range of glutamate antagonists, LY382884 was the only drug in a series of glutamatergic agents that did not produce rotarod deficits at any dose tested (Barton et al., 2003).

Genetic studies in human populations have shown polymorphisms of GRIK3, which encodes the kainate 3 receptor subtype, are associated with schizophrenia. In subjects from northern Italy (Begni et al., 2002), Scandinavia (Djurovic et al., 2009), and India (Ahmad et al., 2009), a polymorphism of the GRIK3 gene was found to be associated with schizophrenia. However, genetic analyses conducted in Japanese (Shibata et al., 2006) and Chinese (Li et al., 2008) populations did not find an association with the GRIK3 polymorphism and schizophrenia.

Altered binding of ${ }^{3} \mathrm{H}$-kainic acid and expression of mRNAs for specific subunits of the kainate receptor have been reported in schizophrenia patients (Beneyto et al., 2007; Deakin et al., 1989; Kerwin et al., 1990; Meador-Woodruff and Healy, 2000; Scarr et al., 2005; Watis et al., 2008). Most studies found reduced ${ }^{3} \mathrm{H}-k a i n i c$ acid binding and reduced expression of select mRNAs encoding subunits of the kainate receptor in specific cortical and hippocampal regions. However, it is difficult to predict changes in function from static measures of receptor binding or mRNA expression. For example, in a previous study with the NRI hypomorphic mice, we found no change in ${ }^{3} \mathrm{H}$-kainic acid binding in any brain region in comparison to the wild type mice (Duncan et al., 2002). By contrast, the mutant mice exhibited markedly increased behavioral sensitivity to challenge with kainic acid (Duncan et al., 2010). Thus, the functional consequences of reduced expression of kainate receptors reported in postmortem studies of schizophrenia are unknown.

Reduced kainate receptor binding and expression of kainate receptor subunit mRNAs in people with schizophrenia could result from a loss of neurons expressing kainate receptors. In a postmortem study of schizophrenia patients, the number of GABAergic neurons specifically expressing the GluK1 subunit of the kainate receptor was reduced by $40 \%$ in the anterior cingulate cortex (Woo et al., 2007). In another postmortem study, the numerical density of neurons exhibiting immunoreactivity for kainic acid receptors was reduced in the orbital frontal cortex (Garey et al., 2006). Excessive activation of kainate receptors is known to produce neurotoxic effects. It is therefore possible that supersensitivity of kainate receptors in select populations of neurons of schizophrenia patients could be involved in the reported reduced number of neurons expressing kainate receptors in cortical regions.

Establishing a role for altered kainate receptor function in the pathophysiology of schizophrenia will require further investigation. However, available postmortem and genetic studies provide hints for alterations in kainate receptors in schizophrenia patients. The activity of selective kainate receptor antagonists to partially normalize behavioral abnormalities in the NRI hypomorphic mouse model provides further incentive to explore the potential of kainate receptor antagonists as novel antipsychotic agents. 


\section{Experimental Procedures}

\subsection{Animals}

Littermate wild type and mutant $N R I^{\text {neo/neo }}$ mice were generated by breeding heterozygotic mice, as previously described (Duncan et al., 2004). Animals from "stock" colonies of 129S6/SvEvTac $N R I^{+/ \text {neo }}$ and C57BL/6J NRI ${ }^{+/ \text {neo }}$ mice (identified by PCR) were used to set up matings to generate experimental animals, i.e., F1 hybrid $N R I^{\text {neo/neo }}$ and $N R I^{+/+}$ littermates. In all cases, a $129 \mathrm{~S} 6 / \mathrm{SvEvTac}{ }^{+/ \text {neo }}$ female was bred to a C57BL/6J ${ }^{+/ \text {neo }}$ male. Experimental and control animals were considered genetically identical, with the caveat that the F1 hybrid NR $1^{\text {neo/neo }}$ mice are homozygous for genes very tightly linked to the NRI gene. However, the C57BL/6J heterozygous mice used to generate the F1 hybrids are at $\mathrm{N} 20$, and therefore this linked region is predicted to be very small. Both male and female mice were used in the studies, with group counter-balanced for gender as much as possible. Mice were 3-7 months of age at the time of testing.

\subsection{Drugs}

(S)-1-(2-Amino-2-carboxyethyl)-3-(2-carboxy-5-phenylthiophene-3ylmethylpyrimidine-2,4-dione) (ACET), and (RS)-2-Amino-3(hydroxy-5-tertbutylisoxazol-4-yl)propionic acid (ATPA) were obtained from Tocris Bioscience, Ellisville, MI. Both drugs were dissolved in 20\% Captisol (Cydex Pharmaceuticals). ACET was injected s.c. and ATPA was injected i.p.

\subsection{Characterization of ACET by the Psychoactive Drug Screening Program}

Although published data indicate that ACET is potent and selective kainate receptor antagonist that has minimal affinity for other glutamate receptor subtypes, limited information has been published about potential non-glutamate receptor off-target sites of action of the drug. To better understand the pharmacology of ACET with respect to kainate receptor specificity, receptor-binding profiles of the drug were assessed across a wide range of receptors. This work was generously provided by the National Institute of Mental Health's Psychoactive Drug Screening Program, contract \# HHSN-271-2008-00025-C (NIMH PDSP). The NIMH PDSP is directed by Bryan L. Roth MD, PhD at the University of North Carolina at Chapel Hill and by Project Officer Jamie Driscol at NIMH, Bethesda MD, USA.

\subsection{Behavioral observations and dose finding after ATPA and ACET administration}

Wild type F1 hybrid mice were treated with ATPA ( $30 \mathrm{mg} / \mathrm{kg}$, i.p.), a selective agonist of the GluK1 subtype of the kainate receptor, placed into individual mouse cages, and monitored for one hour for rigidity and immobility. At this dose, ATPA consistently induced a state of complete immobility and flat body posture, beginning 5-10 min after injection, and lasting approximately $30 \mathrm{~min}$. Pretreatment with ACET $(7.5$ or $15 \mathrm{mg} / \mathrm{kg}$ ) or vehicle, given s.c., occurred one hour before the administration of ATPA, with 5 mice per treatment group.

\subsection{Effects of ACET on acoustic startle and prepulse inhibition}

The acoustic startle measure was based on the reflexive whole-body flinch, or startle response, following exposure to a sudden noise. Animals were tested with a San Diego Instruments SR-Lab system using the procedure described by Paylor and Crawley (1997). Briefly, mice were placed in a small Plexiglas cylinder within a larger, sound-attenuating chamber (San Diego Instruments). The cylinder was seated upon a piezoelectric transducer, which allowed vibrations to be quantified and displayed on a computer. The chamber included a house light, fan, and a loudspeaker for the acoustic stimuli (bursts of white 
noise). Background sound levels (70 dB) and calibration of the acoustic stimuli were confirmed with a digital sound level meter (San Diego Instruments).

The selective kainate receptor antagonist ACET was injected s.c. at doses of $7.5 \mathrm{or} 15 \mathrm{mg} /$ $\mathrm{kg}, 60 \mathrm{~min}$ before placing mice in the startle chambers. Separate cohorts of mice were used for each dose $(\mathrm{N}=18$ wild type and 17 mutant mice for the low dose group, and $\mathrm{N}=25$ wild type and 17 mutant mice for the higher dose group). Each test session consisted of 42 trials, presented following a five-minute habituation period. Seven different types of trials were presented: no-stimulus (NoS) trials, trials with the acoustic startle stimulus ( $40 \mathrm{~ms} ; 120 \mathrm{~dB}$ ) alone, and trials in which a prepulse stimulus ( $20 \mathrm{~ms}$; either $74,78,82,86$, or $90 \mathrm{~dB}$ ) had onset $100 \mathrm{~ms}$ before the onset of the startle stimulus. The different trial types were presented in blocks of 7, in randomized order within each block, with an average intertrial interval of 15 seconds (range: 10 to 20 seconds). Measures were taken of the startle amplitude for each trial, defined as the peak response during a 65-msec sampling window that began with the onset of the startle stimulus. An overall analysis was performed for each subject's data for levels of prepulse inhibition at each prepulse sound level (calculated as 100 - [(response amplitude for prepulse stimulus and startle stimulus together / response amplitude for startle stimulus alone) $\times 100])$.

\subsection{Open field test}

Locomotor activity was after injection with $15 \mathrm{mg} / \mathrm{kg}$ ACET, for 1-hr period in a photocellequipped automated open field $(40 \mathrm{~cm} \times 40 \mathrm{~cm} \times 30 \mathrm{~cm}$; Versamax system, Accuscan Instruments). Activity chambers were contained inside sound-attenuating boxes, equipped with houselights and fans. Measures were taken of horizontal activity and number of rearing movements at 5-min intervals during the test.

\subsection{Statistics}

Behavioral data were first analyzed using an overall repeated measures ANOVA, with the factors genotype (+/+ or neo/neo), treatment (vehicle or ACET), dose $(7.5 \mathrm{or} 15 \mathrm{mg} / \mathrm{kg}$ ), and either decibel level (the repeated measure for the acoustic startle test) or time (the repeated measure for the open field test). The two measures from the startle test were amplitude and prepulse inhibition, each analyzed separately. Because of significant dose effects in the overall analysis, repeated measures ANOVAs with the factors genotype and treatment were conducted for each dose of ACET. Significant effects of ACET were further explored by separate repeated measures ANOVAs for each genotype, with the factor treatment. Fishers Protected Least Significant Difference (PLSD) tests were conducted between group means only when a significant $F$ value was found in the repeated measures ANOVA. For all comparisons, significance was set at $\mathrm{p}<0.05$.

\section{Supplementary Material}

Refer to Web version on PubMed Central for supplementary material.

\section{Acknowledgments}

Supported by The Foundation of Hope, NIH grants MH063398, MH080069, HD03110 and by the National Institute of Mental Health's Psychoactive Drug Screening Program, contract \# HHSN-271-2008-00025-C (NIMH PDSP), directed by Bryan L. Roth, M.D., Ph.D., and by Project Officer Jamie Driscol from the NIH.

The technical assistance of Amanda Kaufman and Randy Nonneman are appreciated greatly. 


\section{References}

Ahmad Y, Bhatia MS, Mediratta PK, Sharma KK, Negi H, Chosdol K, Sinha S. Association between the ionotropic glutamate receptor kainate3 (GRIK3) Ser310Ala polymorphism and schizophrenia in the Indian population. World Journal of Biological Psychiatry. 2009; 10:330-333. [PubMed: 19921975]

Barton ME, Peters SC, Shannon HE. Comparison of the effect of glutamate receptor modulators in the $6 \mathrm{~Hz}$ and maximal electroshock seizure models. Epilepsy Research. 2003; 56:17-26. [PubMed: 14529950]

Begni S, Popoli M, Moraschi S, Bignotti S, Tura GB, Gennarelli M. Association between the ionotropic glutamate receptor kainate 3 (GRIK3) ser310ala polymorphism and schizophrenia. Molecular Psychiatry. 2002; 7:416-418. [PubMed: 11986986]

Beneyto M, Kristiansen LV, Oni-Orisan A, McCullumsmith RE, Meador-Woodruff JH. Abnormal glutamate receptor expression in the medial temporal lobe in schizophrenia and mood disorders. Neuropsychopharmacology. 2007; 32:1888-1902. [PubMed: 17299517]

Dargan SL, Clarke VRJ, Alushin GM, Sherwood JL, Nistico R, Bortolotto ZA, Ogden AM, Bleakman D, Doherty AJ, Lodge D, Mayer ML, Fitzjohn SM, Jane DE, Collingridge GL. ACET is a highly potent and specific kainate receptor antagonist: Characterisation and effects on hippocampal mossy fibre function. Neuropharmacology. 2009; 56:121-130. [PubMed: 18789344]

Deakin JFW, Slater P, Simpson MDC, Gilchrist AC, Skan WJ, Royston MC, Reynolds GP, Cross AJ. Frontal Cortical and Left Temporal Glutamatergic Dysfunction in Schizophrenia. Journal of Neurochemistry. 1989; 52:1781-1786. [PubMed: 2566649]

Djurovic S, Kahler AK, Kulle B, Jonsson EG, Agartz I, Le Hellard S, Hall H, Jakobsen KD, Hansen T, Melle I, Werge T, Steen VM, Andreassen OA. A possible association between schizophrenia and GRIK3 polymorphisms in a multicenter sample of Scandinavian origin (SCOPE). Schizophrenia Research. 2009; 107:242-248. [PubMed: 19022628]

Duncan GE, Miyamoto S, Gu HB, Lieberman JA, Koller BH, Snouwaert JN. Alterations in regional brain metabolism in genetic and pharmacological models of reduced NMDA receptor function. Brain Research. 2002; 951:166-176. [PubMed: 12270494]

Duncan GE, Moy SS, Perez A, Eddy DM, Zinzow WM, Lieberman JA, Snouwaert JN, Koller BH. Deficits in sensorimotor gating and tests of social behavior in a genetic model of reduced NMDA receptor function. Behav.Brain Res. 2004; 153:507-519. [PubMed: 15265649]

Duncan GE, Moy SS, Lieberman JA, Koller BH. Effects of haloperidol, clozapine, and quetiapine on sensorimotor gating in a genetic model of reduced NMDA receptor function. Psychopharmacology. 2006a; 184:190-200. [PubMed: 16362405]

Duncan GE, Moy SS, Lieberman JA, Koller BH. Typical and atypical antipsychotic drug effects on locomotor hyperactivity and deficits in sensorimotor gating in a genetic model of NMDA receptor hypofunction. Pharmacology Biochemistry and Behavior. 2006b; 85:481-491.

Duncan GE, Inada K, Koller BH, Moy SS. Increased sensitivity to kainic acid in a genetic model of reduced NMDA receptor function. Brain Res. 2010; 1307:166-76. [PubMed: 19840778]

Fradley RL, O'Meara GF, Newman RJ, Andrieux A, Job D, Reynolds DS. STOP knockout and NMDA NR1 hypomorphic mice exhibit deficits in sensorimotor gating. Behavioural Brain Research. 2005; 163:257-264. [PubMed: 16046005]

Garey LJ, Von Bussmann KA, Hirsch SR. Decreased numerical density of kainate receptor-positive neurons in the orbitofrontal cortex of chronic schizophrenics. Experimental Brain Research. 2006; 173:234-242.

Halene TB, Ehrlichman RS, Liang Y, Christian EP, Jonak GJ, Gur TL, Blendy JA, Dow HC, Brodkin ES, Schneider F, Gur RC, Siegel SJ. Assessment of NMDA receptor NR1 subunit hypofunction in mice as a model for schizophrenia. Genes Brain and Behavior. 2009; 8:661-675.

Hoo K, Legutko B, Rizkalla G, Deverill M, Hawes CR, Ellis GJ, Stensbold TB, Krogsgaard-Larsen P, Skolnick P, Bleakman D. H-3 ATPA: a high affinity ligand for GluR5 kainate receptors. Neuropharmacology. 1999; 38:1811-1817. [PubMed: 10608276]

Jane DE, Lodge D, Collingridge GL. Kainate receptors: Pharmacology, function and therapeutic potential. Neuropharmacology. 2009; 56:90-113. [PubMed: 18793656] 
Javitt DC, Zukin SR. Recent advances in the phencyclidine model of schizophrenia. American Journal of Psychiatry. 1991; 148:1301-1308. [PubMed: 1654746]

Kerwin R, Patel S, Meldrum B. Quantitative Autoradiographic analysis of glutamate binding sites in the hippocampal formation in normal and schizophrenic brain postmortem. Neuroscience. 1990; 39:25-32. [PubMed: 1982465]

Krystal JH, Karper LP, Seibyl JP, Freeman GK, Delaney R, Bremner JD, Heninger GR, Bowers MB Jr, Charney DS. Subanesthetic effects of the noncompetitive NMDA antagonist, ketamine, in humans. Psychotomimetic, perceptual, cognitive, and neuroendocrine responses. Archives of General Psychiatry. 1994; 51:199-214. [PubMed: 8122957]

Lahti AC, Koffel B, LaPorte D, Tamminga CA. Subanesthetic doses of ketamine stimulate psychosis in schizophrenia. Neuropsychopharmacology. 1995; 13:9-19. [PubMed: 8526975]

Li ZQ, He ZD, Tang W, Tang RQ, Huang K, Xu Z, Xu YF, Li LZ, Li XW, Feng GY, He L, Shi YY. No genetic association between polymorphisms in the kainate-type glutamate receptor gene, GRIK4, and schizophrenia in the Chinese population. Progress in NeuroPsychopharmacology \& Biological Psychiatry. 2008; 32:876-880.

Lieberman JA, Stroup TS, McEvoy JP, Swartz MS, Rosenheck RA, Perkins DO, Keefe RSE, Davis SM, Davis CE, Lebowitz BD, Severe J, Hsiao JK, Investigators C. Effectiveness of antipsychotic drugs in patients with chronic schizophrenia. New England Journal of Medicine. 2005; 353:12091223. [PubMed: 16172203]

Meador-Woodruff JH, Healy DJ. Glutamate receptor expression in schizophrenic brain. Brain Research Reviews. 2000; 31:288-294. [PubMed: 10719155]

Mohn AR, Gainetdinov RR, Caron MG, Koller BH. Mice with reduced NMDA receptor expression display behaviors related to schizophrenia. Cell. 1999; 98:427-436. [PubMed: 10481908]

Moy SS, Perez A, Koller BH, Duncan GE. Amphetamine-induced disruption of prepulse inhibition in mice with reduced NMDA receptor function. Brain Research. 2006; 1089:186-194. [PubMed: 16638606]

Ornstein PL, Arnold MB, Allen NK, Bleisch T, Borromeo PS, Lugar CW, Leander JD, Lodge D, Schoepp DD. Structure-activity studies of 6-substituted decahydroisoquinoline-3-carboxylic acid AMPA receptor antagonists .2. Effects of distal acid bioisosteric substitution, absolute stereochemical preferences, and in vivo activity. Journal of Medicinal Chemistry. 1996; 39:22322244. [PubMed: 8667366]

Ramsey AJ, Laakso A, Cyr M, Sotnikova TD, Salahpour A, Medvedev IO, Dykstra LA, Gainetdinov RR, Caron MG. Genetic NMDA receptor deficiency disrupts acute and chronic effects of cocaine but not amphetamine. Neuropsychopharmacology. 2008; 33:2701-2714. [PubMed: 18185498]

Scarr E, Beneyto M, Meador-Woodruff JH, Dean B. Cortical glutamatergic markers in schizophrenia. Neuropsychopharmacology. 2005; 30:1521-1531. [PubMed: 15886719]

Shibata H, Aramaki T, Sakai M, Ninomiya H, Tashiro N, Iwata N, Ozaki N, Fukumaki Y. Association study of polymorphisms in the GluR7, KA1 and KA2 kainate receptor genes (GRIK3, GRIK4, GPJK5) with schizophrenia. Psychiatry Research. 2006; 141:39-51. [PubMed: 16325263]

Swartz MS, Perkins DO, Stroup TS, Davis SM, Capuano G, Rosenheck RA, Reimherr F, McGee MF, Keefe RSE, McEvoy JP, Hsiao JK, Lieberman JA, Investigators C. Effects of antipsychotic medications on psychosocial functioning in patients with chronic schizophrenia: Findings from the NIMH CATIE Study. American Journal of Psychiatry. 2007; 164:428-436. [PubMed: 17329467]

Watis L, Chen SH, Chua HC, Chong SA, Sim K. Glutamatergic abnormalities of the thalamus in schizophrenia: a systematic review. Journal of Neural Transmission. 2008; 115:493-511. [PubMed: 18301955]

Woo TUW, Shrestha K, Ainstrong C, Minns MM, Walsh JP, Benes FM. Differential alterations of kainate receptor subunits in inhibitory interneurons in the anterior cingulate cortex in schizophrenia and bipolar disorder. Schizophrenia Research. 2007; 96:46-61. [PubMed: 17698324] 


\section{Highlights}

$>\quad$ The effects of a highly selective kainate antagonist, ACET, was examined on altered behavioral responses associated with reduced expression of the NR1 subunit of the NMDA receptors.

$>\quad$ ACET reduced the enhanced acoustic startle response and deficits in sensorimotor gating in NR1 hypomorphic mice.

$>\quad$ The results also provide further support for the idea that selective kainate receptor antagonists could be novel therapeutic candidates for schizophrenia. 


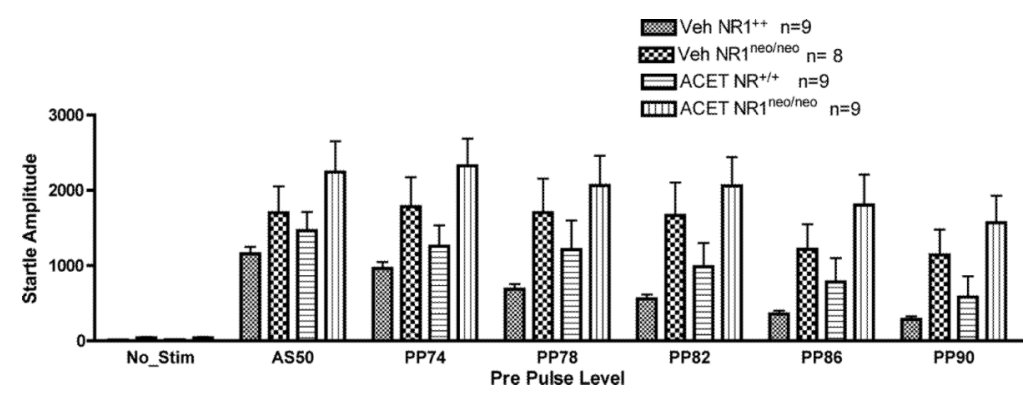

Figure 1.

Acoustic startle response after ACET $(7.5 \mathrm{mg} / \mathrm{kg})$ in wild type and $N R I$ hypomorphic mice. Data are means + SEMs. The number of female and male mice in the different groups are as follows: Veh NR $1^{+/+}$, female $n=5$, male $n=4$; ACET NR $1^{+/+}$, female $n=5$, male $n=4$; Veh $N R I^{\text {neo/neo }}$, female $\mathrm{n}=4$, male $\mathrm{n}=4$, ACET $N R I^{\text {neo/neo }}$, female $\mathrm{n}=5$, male $\mathrm{n}=4$. There was no significant effect of ACET on startle response. 


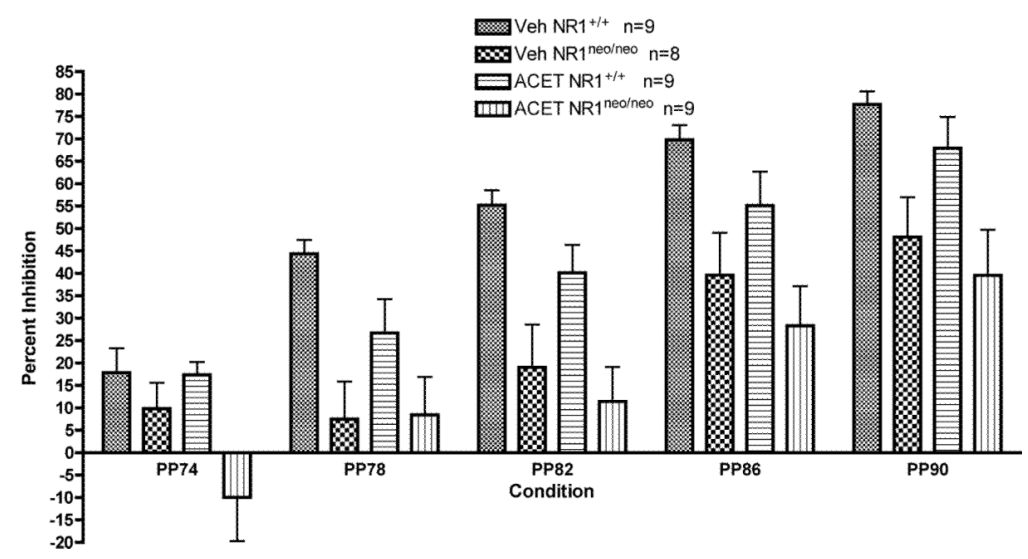

Figure 2.

Prepulse inhibition of acoustic startle after ACET $(15 \mathrm{mg} / \mathrm{kg})$ in wild type and NRI hypomorphic mice. Data shown are means (+ SEM) for each group. There was no significant effect of ACET for any prepulse level for wild type or mutant mice. 


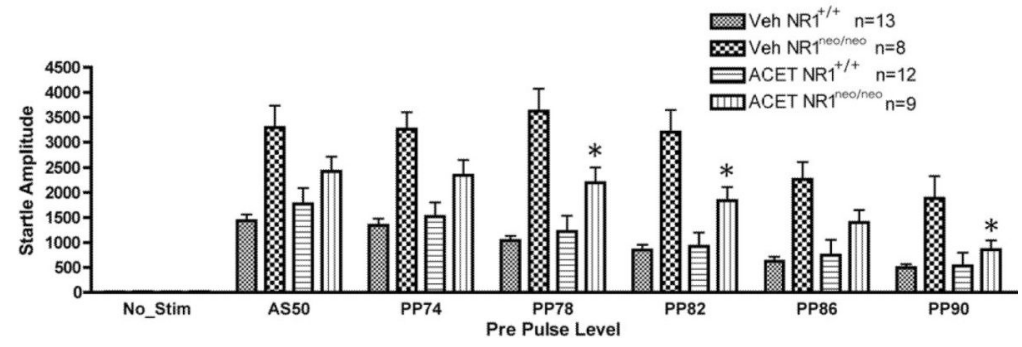

Figure 3.

Acoustic startle response after ACET $(15 \mathrm{mg} / \mathrm{kg})$ in wild type and NRl hypomorphic mice. Data are means + SEMs. The number of female and male mice in the different groups are as follows: Veh $\mathrm{NR} 1^{+/+}$, female $\mathrm{n}=7$, male $\mathrm{n}=6$; ACET $\mathrm{NR} 1^{+/+}$, female $\mathrm{n}=6$, male $\mathrm{n}=6$; Veh $N R I^{\text {neo/neo }}$, female $\mathrm{n}=5$, male $\mathrm{n}=3$, ACET $N R l^{\text {neo/neo }}$, female $\mathrm{n}=5$, male $\mathrm{n}=4 .{ }^{*} \mathrm{p}<.05$ compared to $N R I^{\text {neo/neo-Vehicle. }}$ 


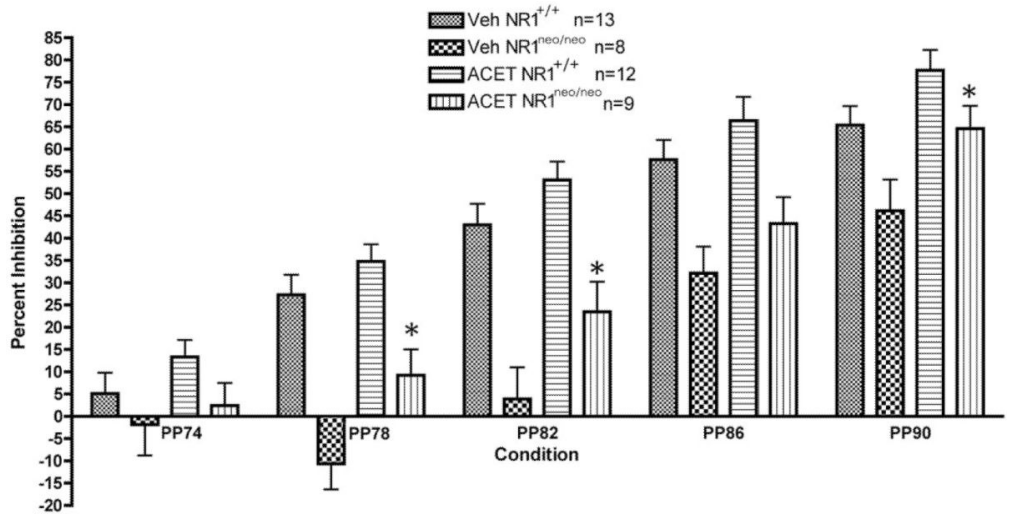

Figure 4.

Prepulse inhibition of acoustic startle after ACET $(15 \mathrm{mg} / \mathrm{kg})$ in wild type and NRI hypomorphic mice. Data shown are means (+ SEM) for each group. $* \mathrm{p}<.05$ compared to $N R 1^{\text {neo/neo-Vehicle. }}$ 


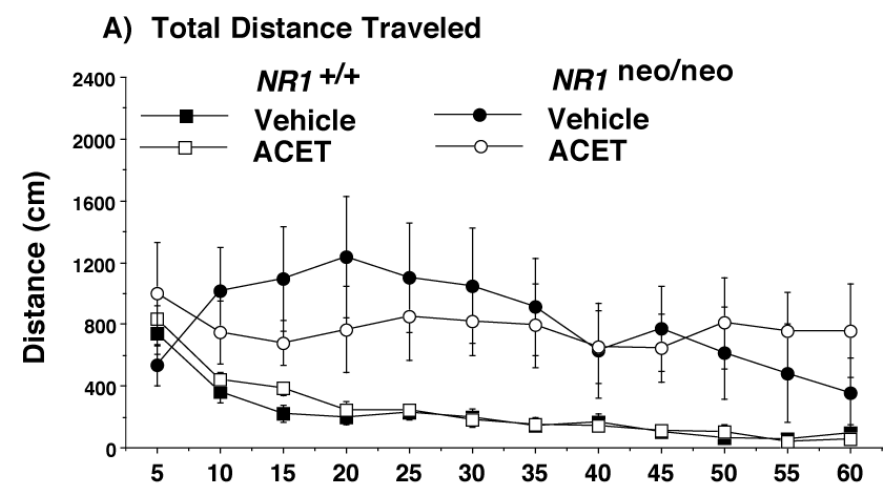

B) Rearing Movements

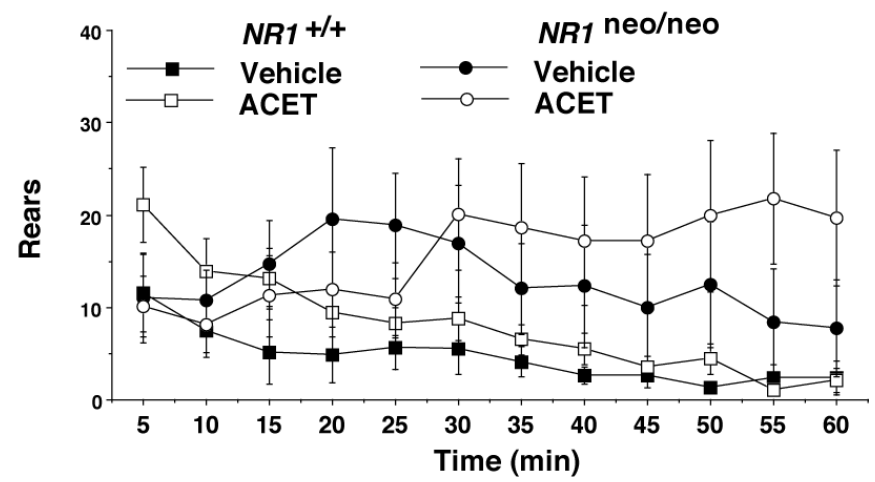

Figure 5.

Horizontal activity (A) and rearing activity (B) in wild type and NRl hypomorphic mice after ACET $(15 \mathrm{mg} / \mathrm{kg})$. Data shown are means $( \pm \mathrm{SEM})$ for each group. There was no significant effect of ACET on horizontal distance traveled or rearing at any time point. 